Journal of Arabic Learning

DOI: $10.18860 / \mathrm{ijazarabi.v4i2.12050}$

ISSN(print): $2620-5912$ | ISSN(online): $2620-5947$

ejournal.uin-malang.ac.id/index.php/ijazarabi/index

\title{
FUZZY DELPHI METHOD APPLICATION IN THE DEVELOPMENT OF I - AQRĀN MODULE FOR ARABIC VOCABULARY CONSOLIDATION
}

\author{
Nabihah Yusof 1 , Harun Baharudin², Mohd Isa Hamzah³ \& \& Nur Izzah \\ Abdul Malek ${ }^{4}$ \\ Faculty of Education, The National University of Malaysia, 43600 Bangi \\ Selangor, Malaysia ${ }^{123}$ \\ Academy of Language Studies, Universiti Teknologi MARA (UiTM), \\ Kelantan Branch 18500 Machang, Kelantan, Malaysia ${ }^{4}$ \\ nabihahphd@gmail.com ${ }^{1}$, harunbaharudin@ukm.edu.my ${ }^{2}$, \\ isa_hamzah@ukm.edu.my ${ }^{3}$,izzahmalek@gmail.com ${ }^{4}$
}

\begin{abstract}
The development of digital systems in learning is gaining attention, especially higher education level. Through the digital world, the use of technological innovation makes the progress of social life and everyday lifestyle is easier than ever before. The use of technology has a positive impact, not only on lifestyle but also have a positive impact on education. This study aims to obtain experts' consensus on the appropriate and accurate elements to be included in the i-Aqran module as an approach to Arabic vocabulary consolidation in the learning of UiTM students. This study uses the Fuzzy Delphi Method (FDM) in which experts' views and consensus on the six main constructs containing 34 tested items are produced. Fifteen (15) experts were selected from seven (7) educational institutions in Malaysia as a study sample. The findings show that these experts arrived at a consensus on 27 tested items in which they have a mean score and experts' evaluation of less than the threshold value $(d) \leq 0.2$. The percentage of these experts' consensus also shows that 27 items tested are above the value of $75 \%$ while 7 remaining tested items prove otherwise and therefore rejected. All items that gained experts' consensus are then listed down in tables based on sequence ranking and its relation from least important to most important items. This study can benefit not only lecturers and students for Arabic vocabulary consolidation but also the developer of learning modules in transforming education through collaboration with interactive technology.
\end{abstract}

Keywords: Fuzzy Delphi Method; Interactive Multimedia; Peer Tutoring; Arab Vocabulary; Consolidation 
Journal of Arabic Learning

DOI: $10.18860 / \mathrm{ijazarabi.v4i2.12050}$

ISSN(print): $2620-5912$ | ISSN(online): $2620-5947$

ejournal.uin-malang.ac.id/index.php/ijazarabi/index/

\section{INTRODUCTION}

The rapid pace of the industrial revolution era of 4.0 proves that it can enhance the interaction and development of digital systems. Human encounters with machines and energy resources has produced highly sophisticated communication devices as well as constructive development in information technology that significantly affect various sectors such as economy, social, education etc. This transformed era is inevitable in that it creates a demand for human resources to be relevant and competitive to continue forward in terms of globalization. As evidence, the demand for human resources through the education system that covers all learning stages i.e. primary, secondary, and tertiary is increasing and this proves that humans can adapt themselves with development of the current industrial revolution 4.0 In fact, people in advanced countries have shown their ability to cope with industrial revolution changes by transforming their educational system, teaching and learning approaches as well as educational goals from traditional to more polished and up to date ones. (Lase, 2019).

Additionally, this transformation in human communication and technology advancement is largely impacting today's world of education and significantly becoming relevant with current learners' interest towards paragogy and cybergogy methods, blended learning, use of WhatsApp, varied functions of gadgets and modern application equipment, gamification learning, skype, facetime, hangout as well as learning that applies heutagogy methods (Abdul Wahab, Muhammad \& Ismail, 2020; Ismail, Wahid \& Hasan, 2019; Ahmad, 2018; Ding, Guan, \& Yu, 2017).

Vocabulary mastery is essential part of language learning but it comes with some great challenges especially when one tries to learn a foreign or third language (target language). Accordingly, a successful language learning can be measured by how much knowledge of words that the learner possesses and his or her ability to use them based on the correct contexts and meanings.

In order to tackle the problems faced in vocabulary learning and mastery, language learners need to use effective methods (Ismail et al., 2016). Nevertheless, finding effective methods requires the learners as well as educators to work together and carefully observe their own teaching and learning styles. Educators need to apply different suitable approaches, analyse and recheck the quality as well as product of their teaching while learners can provide insightful feedback about their own learning preferences. If these crucial steps are neglected or have no clear guidelines, it is possible that they may choose less effective methods. Choosing less effective methods has been identified as one of the main causes for weak vocabulary learning and mastery. In other words, failure of selecting engaging and dynamic teaching and learning methods has caused the process of acquiring Arabic vocabulary to be less successful and tedious for students (Ibrahim \& Mat Teh, 2015; Husin, 2002). 


\section{IJAZ ARABI}

Journal of Arabic Learning

DOI: $10.18860 / \mathrm{ijazarabi.v4i2.12050}$

ISSN(print): $2620-5912$ | ISSN(online): $2620-5947$

ejournal.uin-malang.ac.id/index.php/ijazarabi/index/

Another challenge deals with learning strategies. Learning strategies have been identified to directly influence one's learning style. For successful vocabulary learning to be achieved, learners need to implement self-directed learning. This strategy is necessary for the learning period without teachers' presence. Furthermore, reinforcement for new Arabic vocabulary as well as the existing ones could take place if learners apply the classification model of Schmitt's Vocabulary Learning Strategies (Ismail et al., 2016; Asgari \& Ghazali 2011; Schmitt 2010; Ellis 1985; Lightbown \& Spada, 1994). Nonetheless, it is found that learners do not apply this reinforcement strategy during vocabulary learning (Abdul Basit, Hamzah, \& Baharuddin, 2017).

Apart from that, Yusri et al., (2012) stated that there are a number of reasons that lead to poor learning and acquisition of Arabic vocabulary among UiTM students i.e. implementation of self-directed learning as one of the teaching \& learning (T\&L) methods. However, not all activities under this self-directed learning are ineffective. For example, peer-assisted learning which is categorized under self-directed learning has been proven to be a very widely used strategy in completing group assignments. This view is in line with Yusof et al., (2019), who stated that peer learning is one of the methods found under the concept of selfdirected learning. Self-directed learning is defined as a student-based learning approach.Meanwhile, according to Daud \& Abdul Pisal, (2014), the problems experienced by learners of Arabic are lack of fluency, lack of interaction and declining performance in Arabic interaction due to lack of support from learners' environment.

Lok, (2014) in his writing, argued that conventional learning strategies that involve lecturer-centered learning and individual learning are found to be less effective for acquisition and mastery. Learners easily feel bored and lose focus when lecturers use the one-way communication method in their teaching.

Additionally, Zulkifli et al., (2018) stated that Arabic lessons should be delivered in an engrossing way so that learners can experience a joyful and effective learning environment. To achieve that goal, the instructors need to diversify their ways of teaching so that learners' learning involvement is optimal. Among the important components under the implementation of teaching and learning (T\&L) are the modules that include interactive materials to stimulate learners' potential. According to Vebrianto \& Osman, (2012), teaching and learning are inseparable from the applications of media.This is because, when one implements less interactive elements which are normally found in conventional teaching and learning (T\&L) methods, it results in learners who give less attention and shy to ask questions. The situation worsens when they become less motivated and find the lesson difficult to understand. Hence, in order for a good and highly interactive learning progress to take place, it is critical that educators use materials in form of multimedia or Information and Communication Technology (ICT), as well as develop the right learning modules. 


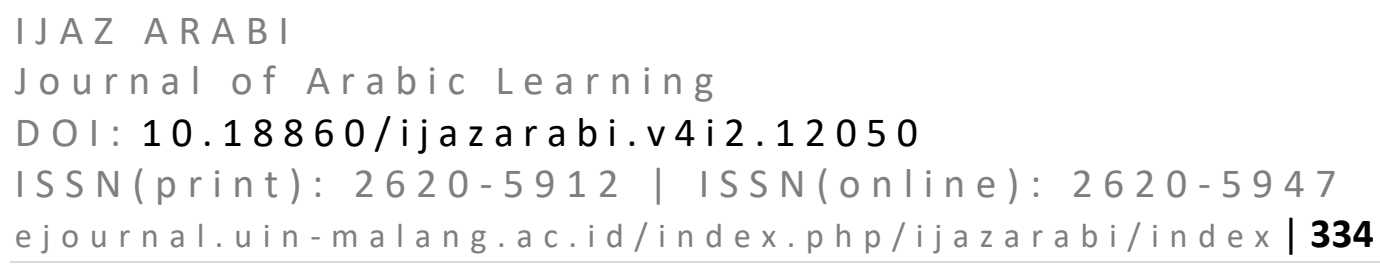

Therefore, based on the issues highlighted in this study, an initiative has been taken in which interactive elements are applied in peer-assisted learning as the method to improve vocabulary learning. These two strategies are combined in hope that the learning process becomes more conducive and effective to consolidate Arabic vocabulary learning of UiTM students.

The principle behind Industrial Revolution 4.0 goals and transformation goal in education has sparked researchers' interest to conduct a study. Hence, this study combined the heutagogy strategy (self-learning) and Paragogy strategy (peerassisted learning) together into one new method i.e. Peer-Assisted Interactive Learning. This new approach was aimed to strengthen Arabic vocabulary learning among UiTM students. In this study, the i-Aqrān Module refers to a module designed for the purpose of consolidating vocabulary learning. The "i - Aqrān" means interactive peer with the letter " $i$ " stands for interactive, while the term "Aqrān" refers to an Arabic word that means peer.

In brief, the main objective of this study was to produce i - Aqrān module design. This module helps in Arabic vocabulary consolidation among learners in UiTM. Through the application of the Fuzzy Delphi Method (FDM), several experts in this field of study were involved in which they responded to the most suitable elements to be integrated into the module. This study was also conducted to answer the research questions namely (1) What is interactive learning of the Arabic language? (2) What is classroom interactivity in Arabic vocabulary learning? (3) What is the need for multimedia technology software in interactive learning of the Arabic language? (4) What are the skills needed by students in interactive learning of the Arabic language? (5) What are the suggested learning activities based on multimedia technology software in interactive learning of the Arabic language? and lastly, (6) What are the proposed forms of assessment in interactive learning of the Arabic language?

\section{METHODS}

This study uses the Fuzzy Delphi Method (FDM) introduced by Murray, Pipino \& Gigch, (1985) and developed by Kaufman \& Gufta, (1998). In other words, it is a combination of Fuzzy Set Theory and the Delphi Method. This shows that the Fuzzy Delphi Method is not a new technique but it is an instrument that 'improves' the existing Delphi Method (Mohd Jamil et al., 2013).

The Fuzzy Delphi Method (FDM) was purposely used in this phase to obtain an agreeable view (consensus) from the group of experts on the items built - in the i - Aqrān module of Arabic vocabulary consolidation among students, based on the previous phase I study. Phase I study was conducted to analyse the needs of UiTM Arabic language lecturers and students all over Malaysia. On the other hand, Phase II study which involves the stage of designing and development this module was conducted on 15 expert panels consisting of 7 institutions such as Universiti Kebangsaan Malaysia (UKM), Universiti Sains Islam Malaysia (USIM), UiTM 


\section{IJAZ ARABI}

Journal of Arabic Learning

DOI: $10.18860 / \mathrm{ijazarabi.v4i2.12050}$

ISSN(print): $2620-5912$ | ISSN(online): $2620-5947$

ejournal.uin-malang.ac.id/index.php/ijazarabi/index/

Shah Alam, UiTM Kelantan Branch, UiTM Terengganu Branch, Zainal Abidin University (UNISZA) and Teacher Education Institution (IPG) Kota Bharu.

The data used in designing and developing $\mathrm{i}$-Aqran module were collected starting from the first week in semester 2 of the 2018/2019 study. Later, a group of experts were selected and then appointed for the purpose of providing feedback and contribution of ideas based on their expertise as an improvement and refinement of the item's content. Prior to collecting the feedback, these experts had been contacted via electronic mail and via short messages (smartphone) for their consent. Upon their agreement to contribute invaluable information for this study, the Fuzzy Delphi questionnaire were later distributed to them via face-to-face and electronic mail.

Subsequently, the data collected were in the form of Likert Scale responses and then converted into numerical data of Fuzzy before being analysed using the Fuzzy Delphi Method (FDM). Specifically, these Fuzzy Delphi data were tabled using Triangular Fuzzy Score and Defuzzification. Triangular Fuzzy Score is estimated to reach the values of $\mathrm{m} 1, \mathrm{~m} 2$, and $\mathrm{m} 3$, which was displayed in the form $(\mathrm{m} 1, \mathrm{~m} 2, \mathrm{~m} 3)$. The value of $\mathrm{m} 1$ represents the minimum value, the value of $\mathrm{m} 2$ represents the reasonable value while the value of $\mathrm{m} 3$ represents the maximum value. The Triangular Fuzzy Score is used to produce a Fuzzy scale (similar to the Likert Scale) intended to translate linguistic variables into fuzzy numbers. The number or score for levels of agreement or Fuzzy scale level was in the form of odd numbers. If the Fuzzy scale is higher, then the data obtained is more precise as shown in Figure 1.

Figure 1: Fuzzy scale on level of agreement

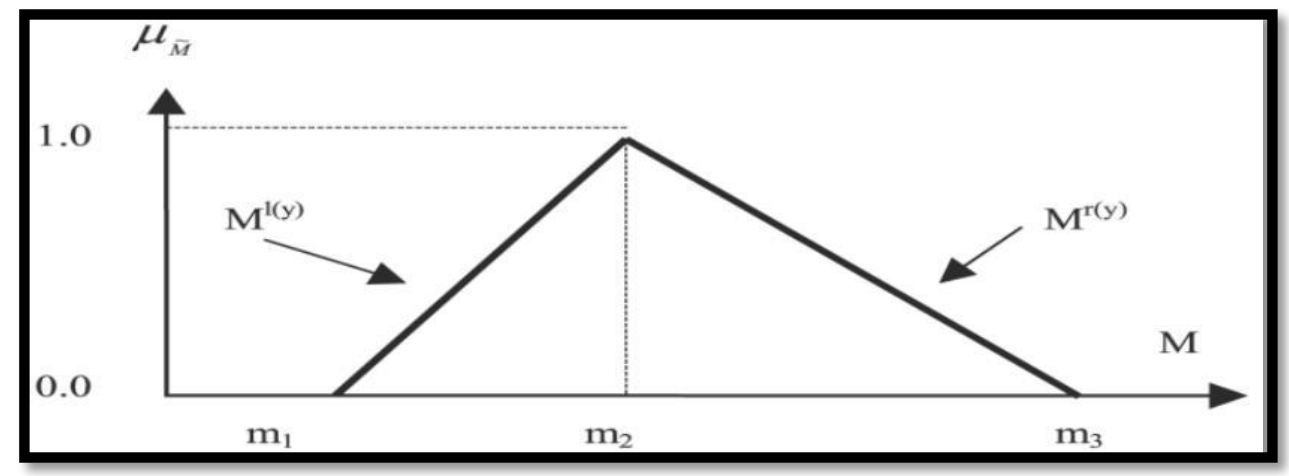

After all the Likert Scale data were collected from the experts, they were analysed using the structured cabling technique. All data was translated into a Triangular Fuzzy Score. The scale used in this study is the 7-point Fuzzy Scale which depicts the higher the number on the scale, the more accurate and precise the data obtained. It is shown in Table 1. 


\section{IJAZ ARAB I}

Journal of Arabic Learning

DOI: $10.18860 / \mathrm{ijazarabi.v4i2.12050}$

ISSN(print): 2620-5912 | ISSN(onIine): 2620-5947

ejournal.uin-malang.ac.id/index.php/ijazarabi/index

Table 1: Fuzzy rating score on seven-point Likert Scale

\begin{tabular}{lll}
\hline Level of Agreement & Likert Scale & Fuzzy Scale \\
\hline Extremely Disagree & 1 & $(0.0,0.0,0.1)$ \\
Strongly Disagree & 2 & $(0.0,0.1,0.3)$ \\
Disagree & 3 & $(0.1,0.3,0.5)$ \\
Somewhat Disagree & 4 & $(0.3,0.5,0.7)$ \\
Agree & 5 & $(0.5,0.7,0.9)$ \\
Strongly Agree & 6 & $(0.7,0.9,1.0)$ \\
Extremely Agree & 7 & $(0.9,1.0,1.0)$ \\
\hline
\end{tabular}

The collected data are then tabled to obtain Fuzzy values $(\mathrm{n} 1, \mathrm{n} 2, \mathrm{n} 3)$ as well as Fuzzy mean values (m1, m2, m3), threshold values, percentages of expert consensus, defuzzification, and item ranking. To derive expert consensus for each item, the threshold value must not exceed 0.2 . On the other hand, the percentage of expert consent should be equal to or above the value of $75 \%$ while the value of defuzzification for each item needs to be above the value of $\alpha$-cut $=0.5$.

\section{RESULTS AND FINDINGS}

Data on Expert Agreement towards Interactive Learning of Arabic language

Table 2: Elements/Items for interactive learning of Arabic language

\begin{tabular}{cl}
\hline No. & \multicolumn{1}{c}{ Elements } \\
\hline 1 & Students collaborate with peers in completing assignments \\
2 & Students spend time discussing lessons with peers \\
3 & Students dare to express an opinion when communicating with peers \\
4 & Students feel comfortable being in a group with peers \\
5 & Students feel confident in communicating spontaneously with their peers \\
\hline
\end{tabular}

The threshold values (D Items) and threshold values (D Construct) of the above elements are shown in Table 3.

Table 3: Threshold value of each element (d item) and the threshold value of construct ( $\mathrm{d}$ construct)

\begin{tabular}{cccccc}
\hline EXPERT & \multicolumn{5}{c}{ Elements } \\
\cline { 2 - 6 } & $\mathbf{1}$ & $\mathbf{2}$ & $\mathbf{3}$ & $\mathbf{4}$ & $\mathbf{5}$ \\
\hline 1 & 0.0 & 0.0 & 0.0 & 0.0 & 0.2 \\
2 & 0.0 & 0.0 & 0.0 & 0.0 & 0.2 \\
3 & 0.2 & 0.2 & 0.1 & 0.1 & $\mathbf{0 . 5}$ \\
4 & 0.0 & 0.0 & 0.0 & 0.0 & 0.2 \\
5 & 0.0 & 0.0 & 0.0 & 0.0 & 0.2 \\
6 & 0.1 & 0.1 & 0.2 & 0.1 & $\mathbf{0 . 5}$ \\
7 & 0.1 & 0.1 & 0.0 & 0.0 & 0.0 \\
8 & 0.2 & 0.2 & 0.1 & 0.1 & 0.4 \\
9 & 0.0 & 0.0 & 0.0 & 0.0 & $\mathbf{0 . 5}$ \\
10 & 0.1 & 0.1 & 0.2 & 0.2 & 0.0 \\
11 & 0.1 & 0.1 & 0.2 & 0.2 & 0.0 \\
12 & 0.1 & 0.1 & 0.2 & 0.2 & 0.2 \\
13 & 0.0 & 0.0 & 0.0 & 0.1 & 0.0 \\
14 & 0.0 & 0.0 & 0.0 & 0.0 & 0.0 \\
15 & 0.0 & 0.0 & 0.0 & 0.0 & 0.2 \\
\hline
\end{tabular}




\section{IJAZ ARABI}

Journal of Arabic Learning

DOI: $10.18860 / \mathrm{ijazarabi.v4i2.12050}$

ISSN(print): 2620-5912 | ISSN(onIine): 2620-5947

ejournal.uin-malang.ac.id/index.php/ijazarabi/index/

\begin{tabular}{llllll}
\hline $\begin{array}{l}\text { Threshold value }(d) \\
\text { Every item }\end{array}$ & 0.12 & 0.12 & 0.11 & 0.10 & 0.27 \\
\hline $\begin{array}{l}\text { Threshold value }(d) \\
\text { construct }\end{array}$ & & $0.12^{*}$ & & & \\
\hline
\end{tabular}

* Method 1: Threshold value $(d) \leq 0.2=$ Accept

Based on Table 3, depicts that there are five items for interactive learning of the Arabic language. Four items recorded a threshold value $(d) \leq 0.2$. This shows that each item under interactive learning of the Arabic language had gained a consensus from experts. If the item scored a threshold value $(d) \leq 0.2$, then it means that the item had reached a consensus among experts (Jusoh, 2018). All these items were tabled according to the logical sequence of importance i.e. 1- most important, 2 - less important and $x$ - the least important. The data are shown in Table 4.

Table 4: Percentages of expert agreement, fuzzy score, consensus, and item rank

\begin{tabular}{|c|c|c|c|c|c|}
\hline No & Elements & $\begin{array}{c}\text { Percentage } \\
\text { of Expert } \\
\text { Agreement } \\
\geq 75 \%\end{array}$ & $\begin{array}{l}\text { Fuzzy } \\
\text { Score } \geq \\
0.5\end{array}$ & Consensus & Rank \\
\hline 1 & $\begin{array}{l}\text { Students collaborate } \\
\text { with peers in } \\
\text { completing } \\
\text { assignments }\end{array}$ & $100.00 \%$ & 0.82 & ACCEPT & 3 \\
\hline 2 & $\begin{array}{l}\text { Students spend time } \\
\text { discussing lessons } \\
\text { with peers }\end{array}$ & $100.00 \%$ & 0.82 & ACCEPT & 4 \\
\hline 3 & $\begin{array}{l}\text { Students dare to } \\
\text { express an opinion } \\
\text { when communicating } \\
\text { with peers }\end{array}$ & $100.00 \%$ & 0.83 & ACCEPT & 2 \\
\hline 4 & $\begin{array}{l}\text { Students feel } \\
\text { comfortable being in } \\
\text { a group with peers }\end{array}$ & & & REJECT & - \\
\hline 5 & $\begin{array}{lr}\text { Students } & \text { feel } \\
\text { confident } & \text { in } \\
\text { communicating } & \\
\text { spontaneously } & \text { with } \\
\text { their peers } & \\
\end{array}$ & $100.00 \%$ & 0.86 & АCCEPT & 1 \\
\hline
\end{tabular}

Based on Table 4, shows that the elements for interactive learning of the Arabic language have successfully obtained expert consensus. "Students feel confident communicating spontaneously with friends" in item (5) becomes a priority among other elements tested. However, there is one item namely item (4) which was rejected from the consensus of experts. 


\section{Expert Agreement Data on Classroom Interactivity in Arabic Vocabulary Learning}

Table 5: Elements for classroom interactivity in Arabic vocabulary learning

\begin{tabular}{|c|c|}
\hline No. & Elements \\
\hline 1 & Students ask their peers to find out the meaning of the new word. \\
\hline 2 & Students repeatedly pronounce the word aloud with peer \\
\hline 3 & Students ask the help of peer to examine the meaning of the new word \\
\hline 4 & Students interact using the words learned with peer \\
\hline 5 & Students use mixed spoken words Example: الفَوَاكَهـ suka أَنَّا \\
\hline
\end{tabular}

Threshold values ( $\mathrm{D}_{\text {Item }}$ ) and the threshold value ( $\mathrm{D}_{\text {Construct }}$ ) for the above elements are depicted in Table 6.

Table 6: Threshold values per element ( $\mathrm{d}$ item) and threshold values construct ( $\mathrm{d}$ construct)

\begin{tabular}{c|c|c|c|c|c}
\hline \multirow{2}{*}{ EXPERT } & \multicolumn{5}{|c}{ Elements } \\
\cline { 2 - 5 } & $\mathbf{1}$ & $\mathbf{2}$ & $\mathbf{3}$ & $\mathbf{4}$ & $\mathbf{5}$ \\
\hline 1 & 0.0 & 0.1 & 0.0 & 0.1 & 0.2 \\
2 & 0.0 & 0.1 & 0.0 & 0.1 & 0.2 \\
3 & 0.2 & 0.2 & 0.1 & 0.1 & $\mathbf{0 . 5}$ \\
4 & 0.0 & 0.1 & 0.0 & 0.1 & 0.2 \\
5 & 0.0 & 0.1 & 0.0 & 0.1 & 0.2 \\
6 & 0.0 & 0.1 & 0.0 & 0.1 & $\mathbf{0 . 5}$ \\
7 & 0.1 & 0.1 & 0.0 & 0.1 & 0.0 \\
8 & 0.2 & 0.2 & 0.1 & 0.2 & $\mathbf{0 . 4}$ \\
9 & 0.0 & 0.1 & 0.0 & 0.1 & $\mathbf{0 . 5}$ \\
10 & 0.1 & $\mathbf{0 . 7}$ & 0.0 & 0.1 & 0.0 \\
11 & 0.1 & 0.1 & 0.2 & 0.1 & 0.0 \\
12 & $\mathbf{0 . 7}$ & $\mathbf{0 . 4}$ & $\mathbf{0 . 4}$ & 0.1 & 0.2 \\
13 & 0.0 & 0.1 & 0.2 & 0.1 & 0.0 \\
14 & 0.0 & 0.1 & 0.0 & 0.1 & 0.0 \\
15 & 0.0 & 0.1 & 0.0 & 0.1 & 0.2 \\
\hline Threshold value $(d)$ & & & & & \\
Every item & 0.16 & 0.20 & 0.12 & 0.13 & 0.27 \\
\hline Threshold value $(d)$ & & & & & \\
construct & & & $0.18^{*}$ & & \\
\hline
\end{tabular}

* Method 1: Threshold value $(d) \leq 0.2=$ Accept

Based on Table 6 , shows that there are five items for classroom interactivity in Arabic vocabulary learning and four items scored a threshold value of $(d) \leq 0.2$. This shows that each item for classroom interactivity in Arabic vocabulary learning had gained a consensus from experts. If the item recorded a threshold value of $(d)$ $\leq 0.2$, then it means that the item had reached consensus among experts (Jusoh, 2018). The items are arranged according to priority rank in Table 7.

Table 7: Percentages of expert agreement, fuzzy score, consensus, and item rank

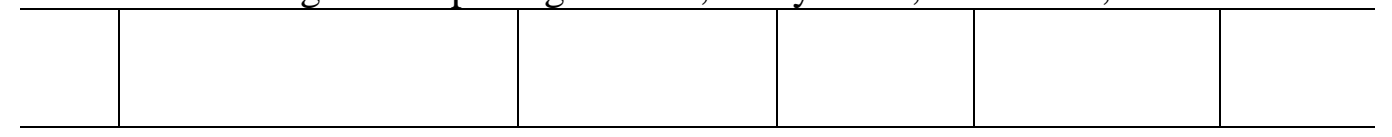


Journal of Arabic Learning

DOI: $10.18860 / \mathrm{ijazarabi.v4i2.12050}$

ISSN(print): 2620-5912 | ISSN(onIine): 2620-5947

ejournal.uin-malang.ac.id/index.php/ijazarabi/index

\begin{tabular}{|c|c|c|c|c|c|}
\hline No & Elements & $\begin{array}{c}\text { Percentage } \\
\text { of Expert } \\
\text { Agreement } \\
\geq 75 \%\end{array}$ & $\begin{array}{l}\text { Fuzzy } \\
\text { Score } \geq \\
0.5\end{array}$ & Consensus & Rank \\
\hline 1 & $\begin{array}{l}\text { Students ask their } \\
\text { peers to find out the } \\
\text { meaning of the new } \\
\text { word. }\end{array}$ & $93.30 \%$ & 0.80 & ACCEPT & 2 \\
\hline 2 & $\begin{array}{l}\text { Students repeatedly } \\
\text { pronounce the word } \\
\text { aloud with peers }\end{array}$ & $86.70 \%$ & 0.78 & ACCEPT & 4 \\
\hline 3 & $\begin{array}{l}\text { Students ask the help } \\
\text { of peers to examine } \\
\text { the meaning of the } \\
\text { new word }\end{array}$ & $93.30 \%$ & 0.83 & ACCEPT & 1 \\
\hline 4 & $\begin{array}{l}\text { Students interact } \\
\text { using the words } \\
\text { learned with peers }\end{array}$ & $100.00 \%$ & 0.79 & ACCEPT & 3 \\
\hline 5 & $\begin{array}{l}\text { Students use mixed } \\
\text { spoken words } \\
\text { Example: اَََْا suka } \\
\text { آلْفَوَاكِهِ }\end{array}$ & & & REJECT & - \\
\hline
\end{tabular}

Based on Table 7, it shows the elements for classroom interactivity in Arabic vocabulary learning that had obtained expert consensus. The item that had gained expert consensus is item (3) which is "Students ask for the help of a friend to check the meaning of a new word". However, there is one item i.e. item (5) which was rejected from the expert's consensus to be put under "the classroom interactivity Arabic vocabulary learning" element.

\section{Expert Agreement Data on the Need for Multimedia Technology Software} Materials in Arabic Interactive Learning (Online Module)

Table 8: Elements for the need for multimedia technology software in the Arabic language interactive learning

\begin{tabular}{l|ll}
\hline No. & \multicolumn{1}{c}{ Elements } \\
\hline 1 & Learning Websites & \\
2 & Graphics & \\
3 & Video/YouTube & \\
4 & Powtoon & \\
5 & Audio & \\
6 & PowerPoint \\
7 & Text \\
8 & Blog & \\
9 & Wiki \\
\hline
\end{tabular}




\section{IJAZ ARABI}

Journal of Arabic Learning

DOI: $10.18860 / \mathrm{ijazarabi.v4i2.12050}$

ISSN(print): $2620-5912$ | ISSN(online): $2620-5947$

ejournal.uin-malang.ac.id/index.php/ijazarabi/index

The threshold values (D Item) and threshold values (D Construct) of the above elements are shown in Table 9.

Table 9: Threshold values per element ( $d$ item) and threshold values of construct (d construct)

\begin{tabular}{|c|c|c|c|c|c|c|c|c|c|}
\hline \multirow[t]{2}{*}{ EXPERT } & \multicolumn{9}{|c|}{ Elements } \\
\hline & 1 & 2 & 3 & 4 & 5 & 6 & 7 & 8 & 9 \\
\hline 1 & 0.0 & 0.2 & 0.0 & 0.0 & 0.0 & 0.0 & 0.0 & 0.0 & 0.0 \\
\hline 2 & 0.0 & 0.0 & 0.0 & 0.0 & 0.0 & 0.0 & 0.0 & 0.0 & 0.0 \\
\hline 3 & 0.0 & 0.1 & 0.2 & 0.1 & 0.2 & 0.1 & 0.2 & 0.1 & 0.1 \\
\hline 4 & 0.0 & 0.1 & 0.3 & 0.1 & 0.3 & 0.1 & 0.1 & 0.1 & 0.1 \\
\hline 5 & 0.0 & 0.1 & 0.3 & 0.1 & 0.3 & 0.1 & 0.1 & 0.1 & 0.1 \\
\hline 6 & 0.0 & 0.0 & 0.3 & 0.2 & 0.3 & 0.2 & 0.2 & 0.2 & 0.2 \\
\hline 7 & 0.0 & 0.0 & 0.3 & 0.1 & 0.3 & 0.1 & 0.1 & 0.1 & 0.1 \\
\hline 8 & 0.0 & 0.1 & 0.2 & 0.1 & 0.2 & 0.1 & 0.1 & 0.1 & 0.1 \\
\hline 9 & 0.0 & 0.1 & 0.3 & 0.1 & 0.3 & 0.1 & 0.1 & 0.1 & 0.1 \\
\hline 10 & 0.0 & 0.2 & 0.2 & 0.2 & 0.2 & 0.2 & 0.2 & 0.2 & 0.2 \\
\hline 11 & 0.0 & 0.2 & 0.2 & 0.2 & 0.2 & 0.2 & 0.2 & 0.2 & 0.2 \\
\hline 12 & 0.0 & 0.0 & 0.3 & 0.0 & 0.3 & 0.0 & 0.0 & 0.0 & 0.0 \\
\hline 13 & 0.0 & 0.0 & 0.2 & 0.0 & 0.2 & 0.0 & 0.0 & 0.0 & 0.0 \\
\hline 14 & 0.0 & 0.1 & 0.2 & 0.1 & 0.2 & 0.1 & 0.1 & 0.1 & 0.2 \\
\hline 15 & 0.0 & 0.0 & 0.2 & 0.1 & 0.2 & 0.0 & 0.0 & 0.03 & 0.0 \\
\hline $\begin{array}{l}\text { Threshold } \\
\text { value }(d) \\
\text { Every item }\end{array}$ & 0.00 & 0.11 & 0.26 & 0.13 & 0.26 & 0.12 & 0.13 & 0.12 & 0.13 \\
\hline $\begin{array}{l}\text { Threshold } \\
\text { value }(d) \\
\text { construct }\end{array}$ & & & & & $0.14^{*}$ & & & & \\
\hline
\end{tabular}

* Method 1: Threshold value $(d) \leq 0.2=$ Accept

Based on Table 9, shows nine items under the element of "Needs of multimedia technology software materials in Arabic interactive learning". There are seven items with a threshold value of $(d) \leq 0.2$. According to Jusoh, (2018), if the item has a threshold value $(d) \leq 0.2$, then it means that the item had reached a consensus among experts for the needs of multimedia technology software materials in interactive learning Arabic.

Table 10: Expert agreement percentages, fuzzy score, consensus, and item rank

\begin{tabular}{c|l|c|c|c|c}
\hline No & Elements & $\begin{array}{c}\text { Percentage of } \\
\text { Expert } \\
\text { Agreement } \geq \mathbf{7 5 \%}\end{array}$ & $\begin{array}{c}\text { Fuzzy Score } \geq \\
\mathbf{0 . 5}\end{array}$ & Consensus & Rank \\
\hline 1 & $\begin{array}{l}\text { Learning } \\
\text { Websites }\end{array}$ & $100.00 \%$ & 0.96 & ACCEPT & 1 \\
\hline 2 & Graphics & $100.00 \%$ & 0.88 & ACCEPT & 3 \\
\hline 3 & Video/YouTube & $100.00 \%$ & 0.88 & ACCEPT & 2 \\
\hline 4 & Powtoon & $100.00 \%$ & 0.86 & ACCEPT & 6 \\
\hline 5 & Audio & & & REJECT & - \\
\hline 6 & PowerPoint & $100.00 \%$ & 0.88 & ACCEPT & 3 \\
\hline
\end{tabular}




\section{IJAZ ARABI}

Journal of Arabic Learning

DOI: $10.18860 / \mathrm{ijazarabi.v4i2.12050}$

ISSN(print): $2620-5912$ | ISSN(online): $2620-5947$

ejournal.uin-malang.ac.id/index.php/ijazarabi/index/341

\begin{tabular}{l|l|l|l|l|l}
\hline 7 & Text & $100.00 \%$ & 0.86 & ACCEPT & 6 \\
\hline 8 & Blog & $100.00 \%$ & 0.87 & ACCEPT & 5 \\
\hline 9 & Wiki & & & REJECT & - \\
\hline
\end{tabular}

Based on Table A, depicts the items under "Needs of multimedia technology software in interactive learning of Arabic". Seven items had acquired consensus from the expert which are the use of the learning website on item (1) the most significant of all other items in those elements. These items are defined as significant in terms of elements needed as multimedia technology software materials in interactive learning of Arabic. However, there are two items namely item (5) and item (9) which were rejected from the consensus of experts.

\section{Expert Agreement Data on Students' Skills Requirements in Interactive Learning of Arabic}

Table 11: Elements for the need for skills in Arabic language interactive learning

\begin{tabular}{c|lc}
\hline No & \multicolumn{1}{|c}{ Elements } \\
\hline 1 & Video / YouTube & \\
2 & Learning Websites & \\
3 & Powtoon & \\
4 & Blog & \\
5 & Wiki & \\
\hline
\end{tabular}

The threshold values (D Item) and threshold values (D Construct) of the above elements are shown in Table 12.

Table 12: Threshold values per element ( $d$ item) and threshold values construct $(d$ construct)

\begin{tabular}{|c|c|c|c|c|c|}
\hline \multirow{2}{*}{ EXPERT } & \multicolumn{5}{|c|}{ Elements } \\
\hline & 1 & 2 & 3 & 4 & 5 \\
\hline 1 & 0.1 & 0.1 & 0.0 & 0.1 & 0.0 \\
\hline 2 & 0.1 & 0.1 & 0.3 & 0.1 & 0.0 \\
\hline 3 & 0.0 & 0.0 & 0.3 & 0.0 & 0.0 \\
\hline 4 & 0.1 & 0.1 & 0.3 & 0.1 & 0.0 \\
\hline 5 & 0.1 & 0.1 & 0.5 & 0.1 & 0.0 \\
\hline 6 & 0.0 & 0.0 & 0.0 & 0.0 & 0.0 \\
\hline 7 & 0.1 & 0.1 & 0.3 & 0.1 & 0.2 \\
\hline 8 & 0.2 & 0.2 & 0.3 & 0.2 & 0.4 \\
\hline 9 & 0.2 & 0.2 & 0.3 & 0.2 & 0.4 \\
\hline 10 & 0.2 & 0.2 & 0.0 & 0.2 & 0.1 \\
\hline 11 & 0.2 & 0.2 & 0.3 & 0.2 & 0.1 \\
\hline 12 & 0.1 & 0.1 & 0.0 & 0.1 & 0.2 \\
\hline 13 & 0.0 & 0.0 & 0.3 & 0.0 & 0.0 \\
\hline 14 & 0.1 & 0.1 & 0.2 & 0.1 & 0.1 \\
\hline 15 & 0.1 & 0.1 & 0.0 & 0.1 & 0.0 \\
\hline $\begin{array}{ll}\text { Threshold value } \\
\text { (d) } \\
\text { Every item }\end{array}$ & 0.15 & 0.15 & 0.30 & 0.15 & 0.09 \\
\hline $\begin{array}{l}\text { Threshold value } \\
\text { (d) } \\
\text { construct }\end{array}$ & & & $0.15^{*}$ & & \\
\hline
\end{tabular}

* Method 1: Threshold value $(\mathrm{d}) \leq 0.2=$ Accept 


\section{IJAZ ARABI}

Journal of Arabic Learning

DOI: $10.18860 / \mathrm{ijazarabi.v4i2.12050}$

ISSN(print): 2620-5912 | ISSN(onIine): 2620-5947

ejournal.uin-malang.ac.id/index.php/ijazarabi/index

Based on Table 12, shows five items for "the need of students' skills in interactive learning of Arabic language". Four items recorded a threshold value of $(d) \leq 0.2$. This indicates that the item had received consensus from experts.

Table 13: Expert agreement percentage, fuzzy score, consensus, and item rank

\begin{tabular}{l|l|c|c|l|c}
\hline No & \multicolumn{1}{|c|}{ Elements } & $\begin{array}{c}\text { Percentage } \\
\text { Of Expert } \\
\text { Agreement } \geq \mathbf{7 5 \%}\end{array}$ & $\begin{array}{c}\text { Fuzzy } \\
\text { Score } \geq \mathbf{0 . 5}\end{array}$ & Consensus & Rank \\
\hline 1 & Video / YouTube & $100.00 \%$ & 0.86 & ACCEPT & 2 \\
2 & Learning Websites & $100.00 \%$ & 0.86 & ACCEPT & 1 \\
3 & Wiki & $100.00 \%$ & 0.80 & ACCEPT & - \\
4 & Blog & $86.67 \%$ & 0.80 & ACCEPT & 3 \\
5 & Powtoon &
\end{tabular}

Based on Table 13, shows the items for "Needs of students' skills in interactive learning of Arabic language". The use of learning websites as item (2) becomes the most significant of all other items in those elements. This shows that the item was a priority from the consensus among experts for the elements in the needs of students' skills in interactive learning Arabic. However, there is one item i.e. item (3) which was omitted from the consensus of experts.

\section{Expert Agreement Data on Proposed Learning Activities by using Multimedia Technology in Arabic Interactive Learning}

Table 14: Elements for proposed learning activities by using multimedia technology

the software in Arabic language interactive learning

\begin{tabular}{c|l}
\hline No & \multicolumn{1}{|c}{ Elements } \\
\hline 1 & Students listen and watch conversation via Video/YouTube \\
2 & Students conduct a discussion with friends \\
3 & Students complete assignment with friends \\
4 & Students get feedback for their answers \\
5 & Students perform constant practice (Drilling) \\
\hline \multicolumn{2}{c}{ The threshold values (D Item) and threshold values (D Construct) of the }
\end{tabular}

above elements are shown in Table 15.

Table 15: Threshold values per element ( $\mathrm{d}$ item) and threshold values construct (d construct)

\begin{tabular}{c|c|c|c|c|c}
\hline \multirow{2}{*}{ EXPERT } & & & Elements & & \\
\cline { 2 - 5 } & $\mathbf{1}$ & $\mathbf{2}$ & $\mathbf{3}$ & $\mathbf{4}$ & $\mathbf{5}$ \\
\hline 1 & 0.0 & 0.0 & 0.0 & 0.1 & 0.2 \\
2 & 0.2 & 0.2 & 0.2 & 0.2 & 0.2 \\
3 & 0.2 & 0.2 & $\mathbf{0 . 4}$ & $\mathbf{0 . 4}$ & $\mathbf{0 . 5}$ \\
4 & 0.0 & 0.0 & 0.0 & 0.1 & 0.2 \\
5 & 0.0 & 0.0 & 0.0 & 0.1 & 0.2 \\
6 & 0.1 & 0.1 & 0.0 & 0.1 & $\mathbf{0 . 5}$
\end{tabular}


Journal of Arabic Learning

DOI: $10.18860 / \mathrm{ijazarabi.v4i2.12050}$

ISSN(print): 2620-5912 | ISSN(onIine): 2620-5947

ejournal.uin-malang.ac.id/index.php/ijazarabi/index

\begin{tabular}{l|l|l|l|l|l}
7 & 0.0 & 0.0 & 0.0 & 0.1 & 0.0 \\
8 & 0.2 & 0.2 & 0.2 & 0.1 & $\mathbf{0 . 4}$ \\
9 & 0.2 & 0.2 & 0.0 & 0.1 & $\mathbf{0 . 5}$ \\
10 & 0.1 & 0.1 & 0.1 & 0.1 & 0.0 \\
11 & 0.1 & 0.1 & 0.1 & 0.1 & 0.0 \\
12 & $\mathbf{0 . 7}$ & $\mathbf{0 . 7}$ & 0.1 & $\mathbf{0 . 4}$ & 0.2 \\
13 & 0.1 & 0.1 & 0.1 & 0.1 & 0.0 \\
14 & 0.0 & 0.0 & 0.0 & 0.1 & 0.0 \\
15 & 0.2 & 0.2 & 0.0 & 0.2 & 0.2 \\
\hline Threshold value $(d)$ & & & & & \\
Every item & 0.19 & 0.19 & 0.15 & 0.18 & 0.27 \\
\hline Threshold value $(d)$ & & & $0.18^{*}$ & & \\
Construct & & & & & \\
\hline
\end{tabular}

* Method 1: Threshold value $(\mathrm{d}) \leq 0.2=$ Accept

Based on Table 15, it shows five items under "Suggested learning activities based on multimedia technology software in Arabic interactive learning". There are 4 items with a threshold value of $(d) \leq 0.2$ that indicates the items had received consensus.

Table 16: Expert agreement percentage, fuzzy score, consensus, and item rank

\begin{tabular}{c|l|l|l|l|c}
\hline No & \multicolumn{1}{|c|}{ Elements } & $\begin{array}{c}\text { Percentage of } \\
\text { Expert } \\
\text { Agreement } \\
\mathbf{7 5 \%}\end{array}$ & $\begin{array}{c}\text { Fuzzy } \\
\text { Score } \\
\mathbf{0 . 5}\end{array}$ & Consensus & Rank \\
\hline 1 & $\begin{array}{l}\text { Students listen and watch } \\
\text { conversation via Video/YouTube }\end{array}$ & $93.30 \%$ & 0.81 & ACCEPT & 1 \\
\hline 2 & $\begin{array}{l}\text { Students conduct a discussion with } \\
\text { friends }\end{array}$ & $93.30 \%$ & 0.81 & ACCEPT & 1 \\
\hline 3 & $\begin{array}{l}\text { Students complete assignment with } \\
\text { friends }\end{array}$ & $93.30 \%$ & 0.81 & ACCEPT & 3 \\
\hline 4 & $\begin{array}{l}\text { Students get feedback for their } \\
\text { answers }\end{array}$ & $86.67 \%$ & 0.77 & ACCEPT & 4 \\
\hline 5 & $\begin{array}{l}\text { Students perform constant practice } \\
\text { (Drilling) }\end{array}$ & & & REJECT & - \\
\hline
\end{tabular}

Based on Table 16, it shows the elements of proposed learning activities based on multimedia technology software in Arabic interactive learning. The most important item is item (1) i.e. students listen and watch conversation through video/Youtube as activities that are based on multimedia technology software. One item, item (5) was omitted from the consensus of experts under the element of "Proposed learning activities based on multimedia technology software in interactive learning of Arabic".

\section{Expert Agreement Data on Proposed Forms of Assessment in Interactive Learning of Arabic}


Journal of Arabic Learning

DOI: $10.18860 / \mathrm{ijazarabi.v4i2.12050}$

ISSN(print): $2620-5912$ | ISSN(onIine): $2620-5947$

ejournal.uin-malang.ac.id/index.php/ijazarabi/index

Table 17: Elements for the proposed forms of assessment in Arabic language interactive

\begin{tabular}{l|l}
\hline No & \multicolumn{1}{c}{ Elements } \\
\hline 1 & Students are evaluated by their peers \\
2 & Students answer interactive quiz \\
3 & Students answer objective questions of a test \\
4 & Students answer subjective questions of a test \\
5 & Final Test of the course/subject taken \\
\hline
\end{tabular}

The threshold value (D Item) and the threshold value (D Construct) of the above elements are shown in Table 18.

Table 18: Threshold values per element ( $d$ item) and threshold values construct (d construct)

\begin{tabular}{c|c|c|c|c|c}
\hline \multirow{2}{*}{ EXPERT } & & & Elements & & \\
\cline { 2 - 6 } & $\mathbf{1}$ & $\mathbf{2}$ & $\mathbf{3}$ & $\mathbf{4}$ & $\mathbf{5}$ \\
\hline 1 & 0.1 & 0.2 & 0.1 & 0.1 & 0.2 \\
2 & 0.1 & 0.2 & 0.1 & 0.2 & 0.2 \\
3 & 0.1 & 0.2 & 0.1 & 0.2 & $\mathbf{0 . 5}$ \\
4 & 0.0 & 0.0 & 0.0 & 0.1 & 0.2 \\
5 & 0.0 & 0.0 & 0.0 & 0.1 & 0.2 \\
6 & 0.0 & $\mathbf{0 . 4}$ & 0.2 & 0.1 & 0.5 \\
7 & 0.0 & 0.0 & 0.0 & 0.1 & 0.0 \\
8 & 0.1 & 0.2 & 0.1 & $\mathbf{0 . 4}$ & $\mathbf{0 . 4}$ \\
9 & 0.1 & 0.2 & 0.1 & 0.2 & $\mathbf{0 . 5}$ \\
10 & 0.2 & 0.1 & 0.2 & 0.1 & 0.0 \\
11 & 0.2 & 0.1 & 0.2 & 0.1 & 0.0 \\
12 & $\mathbf{0 . 5}$ & $\mathbf{0 . 4}$ & $\mathbf{0 . 4}$ & $\mathbf{0 . 4}$ & 0.2 \\
13 & 0.2 & 0.1 & 0.2 & 0.1 & 0.0 \\
14 & 0.0 & 0.0 & 0.0 & 0.1 & 0.0 \\
15 & 0.1 & 0.2 & 0.1 & 0.1 & 0.2 \\
\hline Threshold & 0.16 & 0.20 & 0.17 & 0.19 & 0.27 \\
value $(d)$ & & & & & \\
Every item & & & & & \\
Threshold & & & $0.18 *$ & & \\
value $(d)$ & & & & & \\
Construct & & & & & \\
\hline
\end{tabular}

* Method 1: Threshold value $(d) \leq 0.2=$ Accept

Table 18 shows five items under "Suggested forms of assessment in Arabic interactive learning". Four items recorded a threshold value of $(d) \leq 0.2$. There was an item rejected that is item (5) from the consensus of experts. This indicates that the item has a threshold value of $(d) \leq 0.2$, which means the item had received consensus from experts. 


\section{IJAZ ARAB I}

Journal of Arabic Learning

DOI: $10.18860 / \mathrm{ijazarabi.v4i2.12050}$

ISSN(print): $2620-5912$ | ISSN(online): $2620-5947$

ejournal.uin-malang.ac.id/index.php/ijazarabi/index

Table 19: Percentages of expert agreement, fuzzy score, consensus, and item rank

\begin{tabular}{c|l|l|l|l|c}
\hline No & \multicolumn{1}{|c|}{ Elements } & $\begin{array}{c}\text { Percentage of } \\
\text { Expert } \\
\text { Agreement } \\
\mathbf{7 5 \%}\end{array}$ & $\begin{array}{c}\text { Fuzzy } \\
\text { Score } \geq \\
\mathbf{0 . 5}\end{array}$ & Consensus & Rank \\
\hline 1 & $\begin{array}{l}\text { Students answer interactive } \\
\text { quizzes }\end{array}$ & $93.30 \%$ & 0.84 & ACCEPT & 1 \\
\hline 2 & $\begin{array}{l}\text { Students answer subjective } \\
\text { questions of a test }\end{array}$ & $86.70 \%$ & 0.82 & ACCEPT & 3 \\
\hline 3 & $\begin{array}{l}\text { Students answer objective } \\
\text { questions of a test }\end{array}$ & $93.30 \%$ & 0.83 & ACCEPT & 2 \\
\hline 4 & $\begin{array}{l}\text { Students are assessed based on } \\
\text { peer review; (Tutor: Peer Tutor) }\end{array}$ & $86.67 \%$ & 0.79 & ACCEPT & 4 \\
\hline 5 & $\begin{array}{l}\text { The final test of the } \\
\text { course/subject taken }\end{array}$ & & & REJECT & - \\
\hline
\end{tabular}

Based on Table 19, it indicates the elements for the proposed form of assessment in interactive learning of Arabic. The item being prioritized was item (1) "Students answer the interactive quizzes as the proposed form of assessment in interactive learning of Arabic. Meanwhile, one item i.e. item (5) was rejected from the consensus from experts for the Proposed Form of Assessment in Interactive Learning of Arabic.

Table 20: Results of analysis according to priority rank (1-most important,4-least important)

\begin{tabular}{c|l}
\hline No. & The Interactive Learning of Arabic Language \\
\hline 1 & Students feel confident in communicating spontaneously with their peers \\
2 & Students dare to express an opinion when communicating with peers \\
3 & Students collaborate with peers in completing assignments \\
4 & Students spend time discussing lessons with peers \\
\hline No. & The Elements of Interactivity in Classroom of Arabic Vocabulary \\
& Learning \\
\hline 1 & Students ask the help of peers to examine the meaning of the new word \\
2 & Students ask their peers to find out the meaning of the new word \\
3 & Students interact using the words learned with peers \\
4 & Students repeatedly pronounce the word aloud with peers \\
\hline No. & The Need of Multimedia Technology Software in the Arabic Language \\
& Interactive Learning \\
\hline 1 & Learning Websites \\
2 & Video/YouTube \\
3 & PowerPoint \\
4 & Graphics \\
5 & Blog
\end{tabular}




\begin{tabular}{c|l}
6 & Powtoon \\
7 & Text \\
\hline No. & The Need for Skills in Arabic Language Interactive Learning \\
\hline 1 & Learning Websites \\
2 & Video / YouTube \\
3 & Blog \\
4 & Powtoon \\
\hline No. & Proposed Learning Activities by Using Multimedia Technology in \\
& Arabic Language Interactive Learning \\
\hline 1 & Students listen and watch dialogue via Video/YouTube \\
2 & Students conduct a discussion with friends \\
3 & Students complete assignment with friends \\
4 & Students get feedback from an answer given \\
\hline No & Proposed Form of Assessment in Arabic Language Interactive \\
& Learning \\
\hline 1 & Students answer interactive quizzes \\
2 & Students answer objective questions of a test \\
3 & Students answer subjective questions of a test \\
4 & Students are assessed based on Peer Review (Tutor: Peer tutor) \\
& \\
\hline
\end{tabular}

The findings discussed in this section further elaborate the agreement obtained from the group of experts on the essential elements to be included for the construction of the i - Aqrān module. In general, six main constructs that serves as the pillar of this study containing 34 items believed to be important elements for the module design had been developed and tested. However, only 27 items reached the percentages of the agreement by this group of experts. While 7 remaining items were omitted from each main construct such as the first construct (item 4; students feel comfortable in a group of friends), the second construct (item 5; students use mixed words in their speech by using the first language), the third construct (item 5; audio \& item 9; wiki), fourth construct (item 3; wiki), fifth construct (item 5; drilling) and sixth construct (item 5; a final test of the course/subject).

In the first construct, the interactive learning of Arabic language agreed upon by this group of experts are (1) students feel confident in communicating spontaneously with their peers, (2) students dare to express an opinion when communicating with peers, (3) students collaborate with peers in completing assignments, and (4) students spend time discussing lessons with peers. According to Biju, (2018); Horan, (2016), the main reason for successful learning methods with friends to take place is because students feel more comfortable receiving instructions from other students than instructions from teachers. Students are also more comfortable communicating with friends because they feel they are equal in term of knowledge level for foreign language (Awang et al., 2014)

In the second construct, the elements of interactivity in learning Arabic vocabulary are: (1) students ask the help of peers to examine the meaning of the 
Journal of Arabic Learning

DOI: $10.18860 / \mathrm{ijazarabi.v4i2.12050}$

ISSN(print): $2620-5912$ | ISSN(onIine): $2620-5947$

ejournal.uin-malang.ac.id/index.php/ijazarabi/index /

new word, (2) students ask their peers to find out the meaning of the new word, (3) students interact using the words learned with peers, and (4) students repeatedly pronounce the word aloud with peers. According to Md Yasim, Lubis \& Mohd Noor (2017), in learning Arabic vocabulary, students spend more time asking friends than referring to a dictionary in order to know the new word's meaning. This shows that students are more confident in interacting with friends to get information more accurately than referring to their own dictionary.

Meanwhile, in the third construct, the elements of "needs of multimedia technology software in interactive learning of Arabic language" are: (1) learning websites, (2) video/youtube, (3) powerpoint, (4) graphics, (5) blog, (6) powtoon, and (7) text. Interactive learning also requires some skills to be developed and applied by the students. This can encourage students to be more creative and innovative in learning using interactive multimedia in the classroom. According to Md Sahir \& Mohd Ayub,(2015), learning through video can attract students' focal points through the display of lesson content that is easy for them to understand. Video is also an important element in multimedia as it impacts multimedia applications. The use of integrated video, audio, text, and animation can stimulate students to better understand or master the necessary skills. Besides, the video can be repeated in the screening process and can be easily played on various technology platforms such as computers, mobile phones, tab computers, and so on.

In the fourth construct, the elements of "needs of students' skills in interactive learning of Arabic language" are; (1) learning websites, (2) video / Youtube, (3) blog, and (4) powtoon. According to Ibrahim, Md. Yusoff \& Ghazali, (2016), the use of interactive multimedia in teaching and learning is very effective and successfully creates a more innovative environment. Lecturers play an important role in generating students' thinking that leads them to having a high level of imagination and creativity in the learning process.

In the fifth construct, the elements of "proposed learning activities based on multimedia technology software in interactive learning of Arabic language" are : (1) students listen and watch conversation through video/youtube, (2) students make discussions with friends, (3) students do assignments with friends and (3) students get feedback for answers given. Ishak, Mat Nor \& Ahmad, (2017) argued that interactive learning emphasizes elements of two-way interaction not only in the conventional learning process but also between students and systems in computer-assisted learning (media materials). According to their study as well, it is inevitable for interactive learning to include computer-aided elements. This is because interactive learning impact can only be successfully obtained based on the use of stimulus or material be it in form of pictures or dialogues, tutorials, and feedback. By doing such interactive learning activities, it may lead to a selfdeveloped teaching and learning process by using all learning instruments available.

Next in the sixth construct, the elements of "proposed form of assessment in interactive learning of Arabic language" are: (1) students answer interactive 
quizzes, (2) students answer objective test questions, (3) students answer subjective test questions and (4) students are evaluated by peer review (Peer tutor: mentor). The main purpose of assessment is to provide continuous feedback to students so that their learning can continue to be improved. The assessment shows whether students have achieved the expected teaching objectives and convinces teachers of the effectiveness of strategies applied in improving teaching, learning, and student performance in the future (Abdul Karim \& Ramlee, 2018).

According to Yusof et al., (2020), as the Education Revolution 4.0 is advancing, it goes in line with student-centered learning. In other words, educators need to put their focus on developing this approach to betterment. In the context of student-centered learning, other than considering the teaching methods, educators also need to consider teaching and learning resources which contain other significant aspects of the teaching and learning process.

\section{CONCLUSION}

The application of the Fuzzy Delphi Method (FDM) in this research acts as a reference and guide for Arabic linguists on how to determine the appropriate elements to be applied into the design and development phase of the i - Aqrān Module. Based on the discussion made, a learning material aid in form of a module has been successfully built and is expected to meet the needs of students who take the Arabic Language II course at UiTM. Aside from using this module as the main reference, lecturers can also combine it with other techniques or methods to improvise any shortcomings or weaknesses occur when it is implemented to the different background of learners. In addition, selection of methods that focus on effective self-learning activities will create active involvement throughout the learning process. All in all, this study has successfully described the design and development research of the i - Aqrān Module for Arabic vocabulary consolidation among third language students by involving the Fuzzy Delphi Method (FDM) based on the consensus and feedback of field experts. It is hoped that the process of this module development can help other researchers to make improvements and refinements in terms of learning modules.

\section{REFERENCES}

Abdul Basit, N.F., Hamzah, M.I. \& Baharuddin, H. (2017). Strategi Kognitif Dalam Pembelajaran Kosa Kata Bahasa Arab. Journal of Advanced Research in Social and Behavioural Sciences 6, Issue 1 (2017) 41-51. ISSN: 2462-1951

Abdul Karim, Z. \& Ramlee, J. (2018). Penilaian Rakan Sebaya dan Penggunaan Aplikasi Letsrecap dalam Interaksi Lisan. Seminar Bahasa Melayu 2018.

Abdul Wahab, N., Muhammad, N., Ismail, M.S. (2020). Analisis Keberkesanan Penggunaan ICT Dalam Mendepani Gelombang Revolusi Industri 4.0 Dalam Kalangan Pelajar Di Negeri Terengganu, Malaysia. Asian People Journal 2020, Vol 3(1), 101-109. E-Issn: 2600-8971. 


\section{IJAZ ARAB I}

Journal of Arabic Learning

DOI: $10.18860 / \mathrm{ijazarabi.v4i2.12050}$

ISSN(print): 2620-5912 | ISSN(onIine): 2620-5947

ejournal.uin-malang.ac.id/index.php/ijazarabi/index/ $\mathbf{3 4 9}$

Ahmad,I. (2018). Proses Pembelajaran Digital Dalam Era Revolusi Industri 4.0. Jakarta: Dirjen Pembelajaran dan Kemahasiswaan Kemristekdikti.

Asgari, A, \& Ghazali Mustapha. (2011). The type of vocabulary learning strategies used by ESL students in Universiti Putra Malaysia. English Language Teaching, 4(2), 84-90

Awang, N.A., Embong, R., Mustafa, Z. \& Yaacob, A. (2014). Strategi Pembelajaran Bersama Rakan Sebaya Untuk Meningkatkan Kemahiran Bertutur Bahasa Arab Dalam Kalangan Pelajar Bukan Penutur Jati Di Unisza . Prosiding Seminar Pengajaran \& Pembelajaran Bahasa Arab 2014. ISBN 978-967-5478-78-9.

Biju, S.M. (2018). Benefits of Working in Pairs in Problem Solving and Algorithms - Action Research. Athens Journal of Education. Vol. X, No. Y.

Daud, N. \& Abdul Pisal, N. (2014). Permasalahan Pertuturan Dalam Bahasa Arab Sebagai Bahasa Kedua. GEMA Online ${ }^{\circledR}$ Journal of Language Studies. Volume 14(1), February 2014.

Ding, D., Guan, C., \& Yu, Y. (2017). Game-Based learning in tertiary education: A new learning experience for the Generation Z. International Journal of Information and Education Technology,7(2), 148-157.

Ellis, R. (1985). Understanding second language acquisition. Oxford University Press

Gros, B. (2016). "The Design of Smart Educational Environments", Smart Learning Environments, Vol. 3, No. 15, Springer Open.

Horan, T., (2016). Create Your School Library Writing Center: Grades 7-12. Santa Barbara: ABC-CLIO.

Huang, Cheng. (2015). Emerging Issues In Smart Learning. Springer-Verlag Heidelberg, Lecture Notes in Educational Technology, v.

Husin, S.( 2002). Penguasaan Perbendaharaan Kata Bahasa Arab di Kalangan Pelajarpelajar Tingkatan Tiga: Satu Kajian Kes di Sekolah Menengah Kebangsaan Agama Negeri Melaka. Tesis Sarjana. Universiti Malaya

Ibrahim, F. \& Mat Teh, K.S. (2015). Pengaruh Permainan Bahasa Terhadap Motivasi Murid Sekolah Rendah Dalam Pembelajaran Perbendaharaan Kata Bahasa Arab. Tinta Artikulasi Membina Ummah . 1(2), 2015 41-50, e-ISSN: 2289-960X.

Ibrahim,N.H., Md. Yusoff, M.F. \& Ghazali, N. (2016) . Multimedia Interaktif Mempertingkatkan Pengajaran Dan Pembelajaran Kursus Bahasa Melayu Pengurusan (Sblm 1053) Dalam Kalangan Pelajar Universiti Utara Malaysia. International Seminar on Generating Knowledge Through Research. UUMUMSIDA, 25-27 October 2016, Universiti Utara Malaysia, Malaysia. ISSN. 2548-6160.

Ishak, H., Mat Nor, Z. \& Ahmad, A. (2017). Pembelajaran Interaktif Berasaskan Aplikasi Kahoot dalam Pengajaran Abad Ke-21. Seminar Serantau 2017. 


\section{IJAZ ARABI}

Journal of Arabic Learning

DOI: $10.18860 / \mathrm{ijazarabi.v4i2.12050}$

ISSN(print): 2620-5912 | ISSN(onIine): 2620-5947

ejournal.uin-malang.ac.id/index.php/ijazarabi/index/

Ismail, N. A., Wahid, A. N. \& Hasan, M. S. (2019). Meningkatkan Efikasi Kendiri Guru Di Malaysia Terhadap Kecenderungan Pembelajaran Generasi Z Dan Alpha. J.Manag. Oper. Res. (JoMOR), 1(13), 1-8.

Ismail, M.Z., Abu Bakar, K., Nik Mustapha, N.F. \& M Rouyan, N. (2016). Strategi Pembelajaran Kosa Kata Berimbuhan Bahasa Arab. Malaysian Journal of Learning and Instruction. Vol. 13 (2016): 113-133.

Jusoh, M.R. (2018). Reka Bentuk Dan Pembangunan Modul Pembelajaran Tatabahasa Arab Di Institut Pendidikan Guru Malaysia. Tesis Doktor Falsafah. Universiti Kebangsaan Malaysia.

Kaufmann, A.,\& Gupta,M.,M. (1998). Fuzzy Mathematical Models in Enginering and Management Science. Elsevier Science Publishers, North-Holland, Amsterdam, N.Y.

Lase, D. (2019). Pendidikan di Era Revolusi Industri 4.0. Jurnal Sunderman. ISSN : 1979-3588.

Lightbown, P. M., \& Spada, N. (1994). How language are learned. Oxford University Press.

Lok, W. F. (2014). Penggunaan "Peer Tutoring" Dalam Pembelajaran Kimia Organik Di Kalangan Pelajar Matrikulasi. Paper presented at the Konvensyen Kebangsaan Pendidikan Guru 2014, Port Dickson, Negeri Sembilan, Malaysia.

Md Sahir, A. \& Mohd Ayub, A.F. (2015). Keberkesanan Penggunaan Video dalam Amali Masakan. International Journal of Education and Training (InjET) 1(2) November: 1-8 (2015).

Md Yasim, I.M., Lubis, M.A. \& Mohd Noor, Z.A. (2017). Penggunaan Teknik Pembelajaran Aspek Kosa Kata Bahasa Arab Dalam Kalangan Murid. ASEAN Comparative Education Research Journal on Islam and Civilization (ACER-J.) Volume 1(1) January 2017, 14-24.

Mohd Jamil, M.R., Hussin, Z., Mat Noh, N.R., Sapar, A.A. \& Alias, N. (2013). Application of Fuzzy Delphi Method in Educational Research. Design and Developmental Research. Dlm. Saedah Siraj, Norlidah Alias, Dorothy DeWitt \& Zaharah Hussin (pnyt). Kuala Lumpur: Pearson Malaysia Sdn. Bhd.

Murray, T.J., Pipino, L. L \& Gigch, J. P. (1985). A pilot study of fuzzy set modification of Delphi", Human System Management, 6-80.

Vebrianto, R. \& Osman, K. (2012). Keberkesanan Penggunaan Pelbagai Media Pengajaran dalam Meningkatkan Kemahiran Proses Sains dalam Kalangan Pelajar. Jurnal Pendidikan Malaysia. 37(1)(2012): 1-11.

Yusof, N., Baharudin, H., Yusoff, N.M.R.N. \& Sjahrony. A. (2019). I - Aqran Module Construction For Arabic Vocabulary Consolidation: A Needs Analysis. Religación Revista De Ciencias Sociales YHumanidades. Vol 4. No 21. Quito Trimestral Número Especial Noviembre 2019. 57 - 65. ISSN: 2477-9083. 
Journal of Arabic Learning

DOI: $10.18860 / \mathrm{ijazarabi.v4i2.12050}$

ISSN(print): 2620-5912 | ISSN(onIine): 2620-5947

ejournal.uin-malang.ac.id/index.php/ijazarabi/index/351

Yusof, N., Baharudin, Abdul Malek, N.I. \& Hamzah, M.I. (2020). Lecturer's Need Analysis For i - Aqran Modile in Arabic Vocabulary Consolidation 2020 Aming UiTM Learners. Hamdard Islamicus. Vol 43 No.S.2 (2020), 66 - 82

Yusri, G., Yusoff, N.M.R.N. \& Shah, P.M., Wah, W.H. \& Hassan, A.T. (2012). Penggunaan Strategi Belajar Bersama Rakan dalam Kalangan Pelajar Kursus Bahasa Arab di Universiti Teknologi Mara (UiTM). Asia Pacific Journal of Educators and Education, Vol. 27, 37-50, 2012.

Zulkifli, M.S., Jamali, H.N., Hj Iksan, H. \& Ismail, A. (2018). Modul Pengajaran Dan Pembelajaran Interaktif Bahasa Arab Di Pusat Bahasa Arab Selangor (PBAS). Jurnal Sultan Alauddin Sulaiman Shah. Vol 5 Bil 1 (2018). e-ISSN: 2289-8042. 